\title{
Działalność Zarządu Głównego Polskiego Towarzystwa Onkologicznego w latach 1978-1982
}

\author{
Jan Berner, Leszek Woźniak
}

Polish Oncological Society: activities of the Board 1978-1982

W latach 1978-1982 przewodniczącym Zarządu Głównego Polskiego Towarzystwa Onkologicznego był prof. dr hab. med. Leszek Woźniak. Sekretarzem Zarządu Głównego PTO był prof. dr hab. med. Jan Berner.

W 1978 r., po likwidacji Ośrodka Naukowo-Badawczego Akademii Medycznej w Łodzi, którego Kierownikiem przez blisko 10 lat był prof. Leszek Woźniak, rozpoczęto formowanie pierwszej w Polsce wieloczłonowej Katedry Onkologii. Pracownia diagnostyki patomorfologicznej tego Ośrodka została przeniesiona na teren Regionalnego Ośrodka Onkologicznego w Wojewódzkim Szpitalu im. Mikołaja Kopernika wŁodzi. Kierownictwo Zakładu Patomorfologii Onkologicznej objął prof. Leszek Woźniak, zaś Klinikę Chirurgii Onkologicznej organizował od podstaw prof. Jan Berner, opierając się na bazie Oddziału Chirurgii Regionalnego Ośrodka Onkologicznego. W tymże roku 1978 walne zgromadzenie członków Polskiego Towarzystwa Onkologicznego powołało na prezesa Zarządu Głównego prof. Leszka Woźniaka i zaakceptowało jego wniosek, aby sekretarzem Zarządu Głównego został prof. Jan Berner.

Główne działania Zarządu PTO w latach 1978-1980 polegały na nawiązywaniu współpracy z medycznymi ośrodkami akademickimi w zakresie reorganizacji i doskonalenia przeddyplomowego nauczania onkologii. Wiązało się to z koniecznością utworzenia w akademiach medycznych samodzielnych jednostek dydaktyczno-naukowych o profilu onkologicznym. Pod koniec kadencji Zarządu Głównego PTO zostały przygotowane przez ośrodek łódzki założenia programu uwzględniającego po raz pierwszy treści dydaktyczne związane z opieką paliatywną, całkowicie dotychczas pomijaną w edukacji lekarzy w Polsce.

W latach 1975-1985, a więc częściowo w okresie prezesury w PTO, prof. Leszek Woźniak koordynował w skali całego kraju badania naukowe prowadzone w akademiach medycznych w dziedzinie diagnostyki patomorfologicznej i radiologicznej nowotworów. Odbywało się to w ramach programów badawczych PR-6 i CPBR-11,5. Rozpoczął także współpracę $z$ Łódzkim Zakładem Techniki Obliczeniowej (ZETO) i zastosował w badaniach onkologicznych technikę komputerową. W roku 1981 prof. Leszek Woźniak i prof. Jan Steffen zostali delegowani do Genewy na naradę ekspertów do spraw przeddyplomowego nauczania onkologii

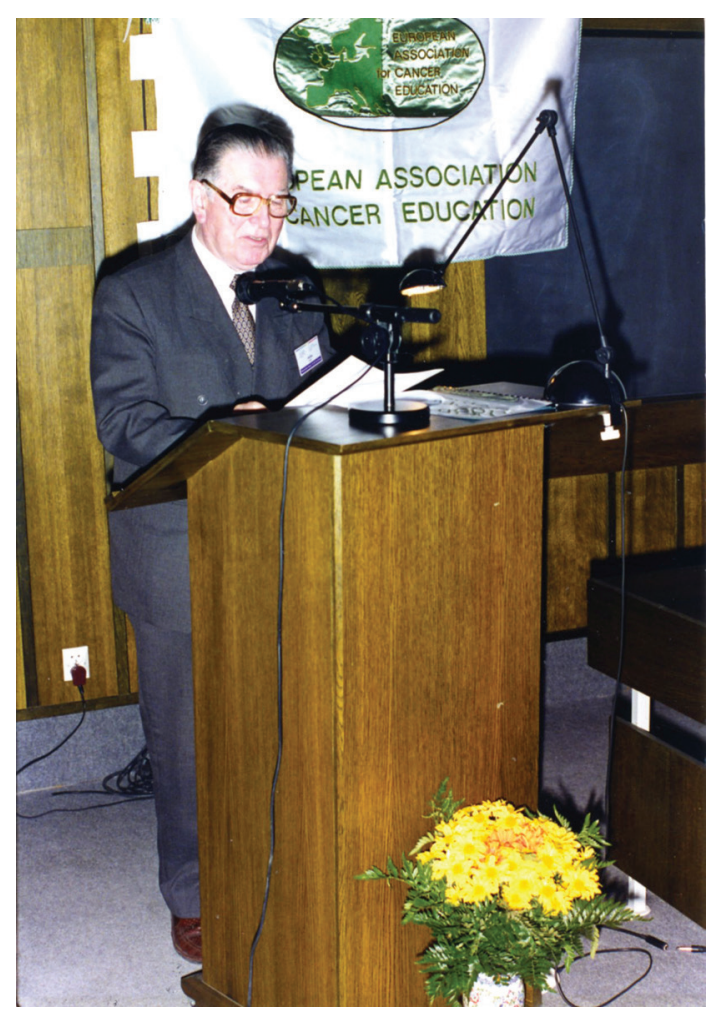

Wystąpienie prof. Leszka Woźniaka na Konferencji EACE 


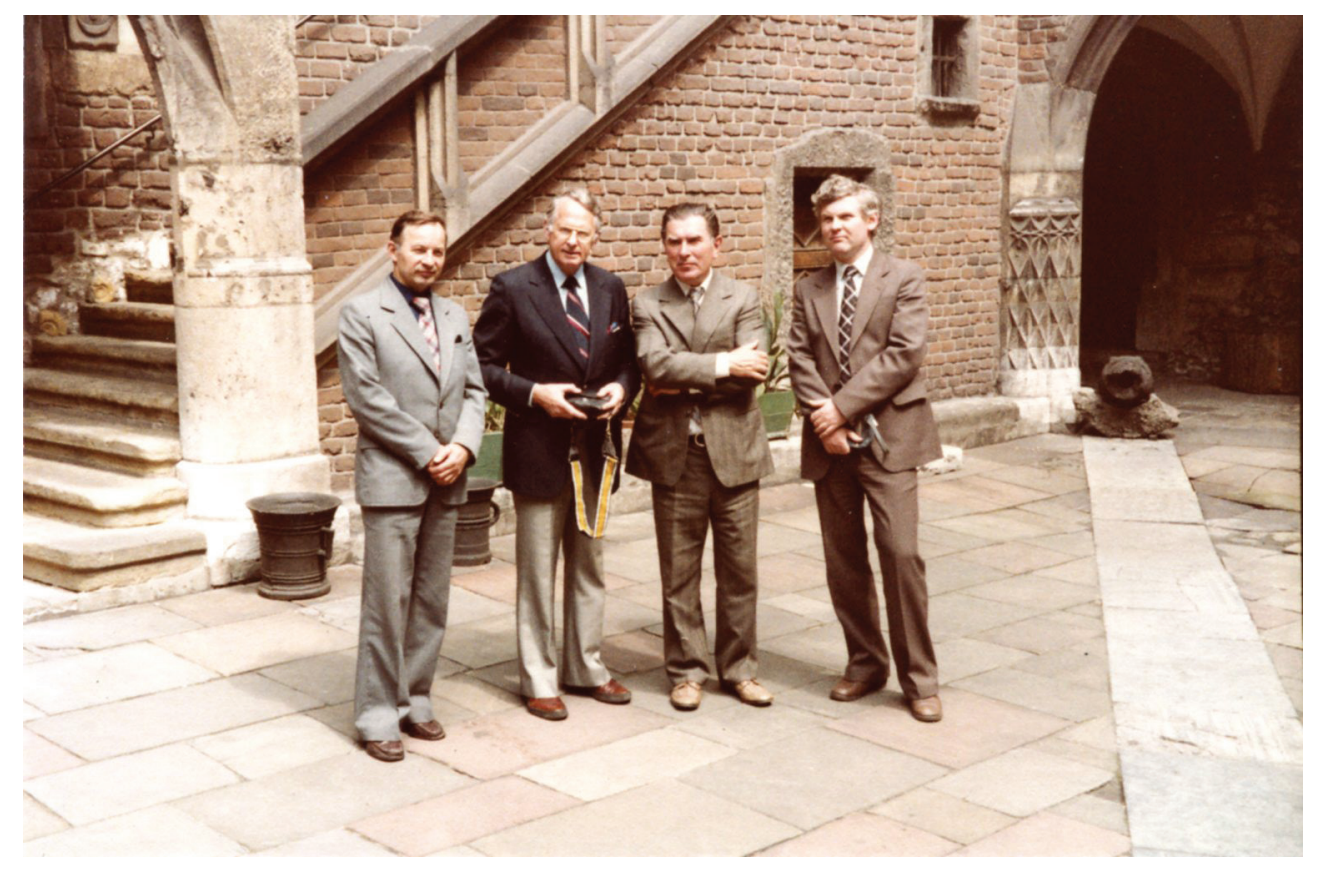

W Krakowie z dr. Reedem (Kanada), dr. Reinfussem (Kraków) i dr W. Ricem

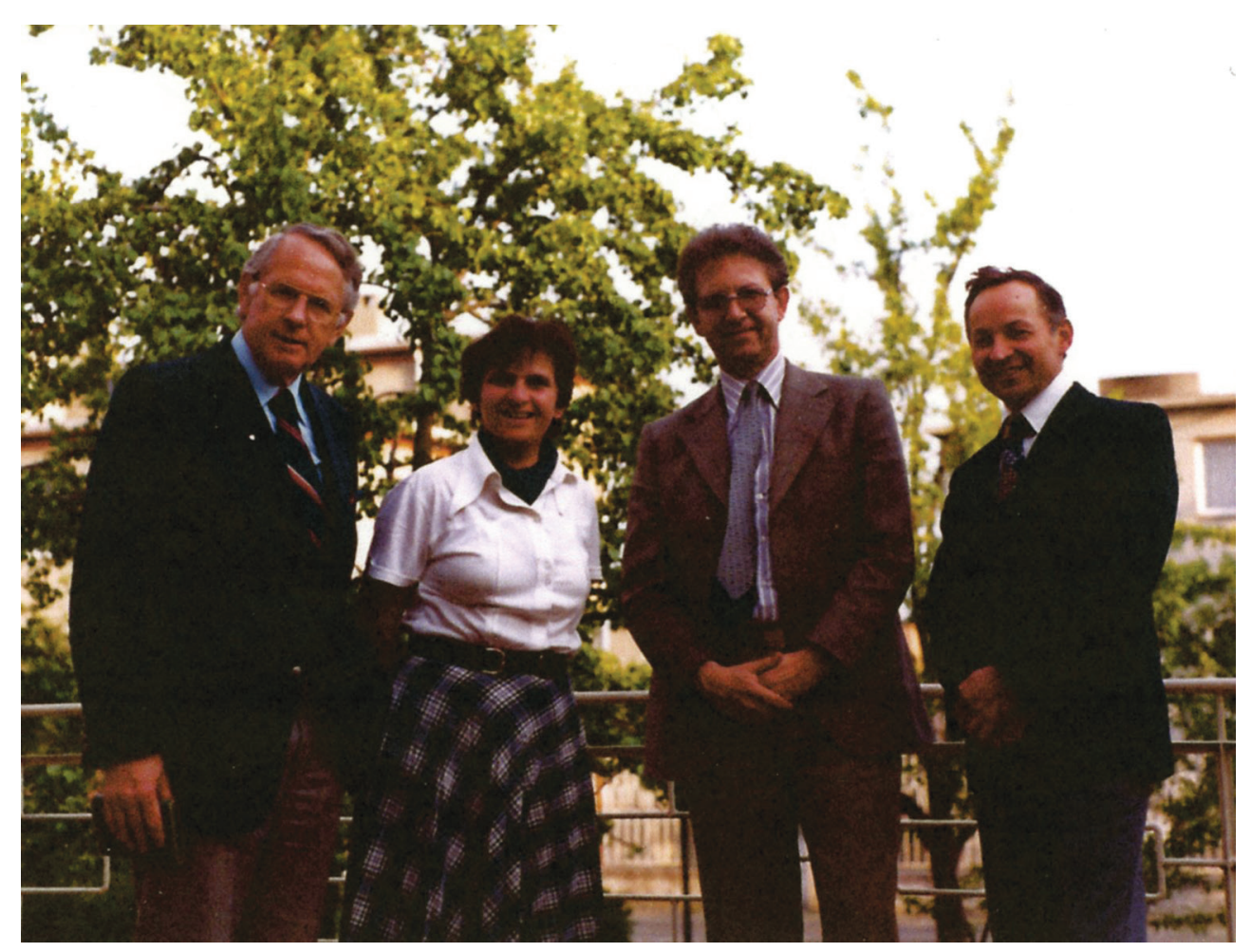

Dr W. Rice i W.W. Reed w Pabianicach na zaproszenie Lidii i Jana Bernerów podczas wizyty w Ośrodkach Onkologicznych w Polsce

w Europie i Afryce Północnej. W naradzie tej brali udział dziekani szkół medycznych oraz przedstawiciele WHO, UICC i EORTC. Prof. L. Woźniak przedstawił tam sytuację obecną i plany edukacji onkologicznej w uczelniach medycznych w Polsce.
W maju 1981 roku prof. Leszek Woźniak został pierwszym elekcyjnie wybranym rektorem Akademii Medycznej w Łodzi, a prof. Jan Berner — elekcyjnie wybranym dziekanem Wydziału Lekarskiego tejże Uczelni. Funkcje te spełniali oni przez dwie kadencje, tj. do września 1987 roku. 
Funkcje prezesa i sekretarza generalnego PTO dobiegły końca w 1982 roku. Prof. Leszek Woźniak został wybrany przewodniczącym Rady Naukowej Centrum Onkologii w Warszawie. W tym czasie, reprezentując PTO, prof. L. Woźniaki prof. J. Berner brali czynny udział w ogólnoświatowym sympozjum w Egipcie, w Ismailli. Dotyczyło ono nowoczesnych programów edukacji lekarskiej, mających zastosowanie w 20 eksperymentalnych wydziałach lekarskich o profilu społeczno-medycznym (community oriented medicine). Delegaci z Łodzi wygłosili w Ismailli dwa referaty na temat profesjonalnej i społecznej edukacji onkologicznej w Polsce. Referaty te zostały opublikowane w materiałach sympozjum. Prof. J. Berner od roku 1981 brał udział w badaniach nad rozpoznawaniem i leczeniem raka żołądka w ramach programu rządowego. Następnie uczestniczył w wieloośrodkowych badaniach dotyczących rozpoznawania i leczenia raka żołądka, koordynowanych przez prof. Tadeusza Popielę z Uniwersytetu Jagiellońskiego. W ramach kontaktów w roku 1981 z EORTC prof. Jan Berner do 1990 roku brał udział w badaniach wieloośrodkowych, dotyczących raka piersi w Breast Cancer Cooperative Group, dotyczących raka piersi.

W roku 1989 w ramach Zarządu Głównego PTO została utworzona pięcioosobowa komisja ds. przeddyplomowego nauczania onkologii na wydziałach lekarskich uczelni medycznych. Przewodniczącym tej Komisji od roku 1990 był prof. L. Woźniak, który opracował program zintegrowany z założeniami i wytycznymi programu Unii Europejskiej, zatwierdzony przez WHO, UICC i EORFC w roku 1988.

Pod koniec kadencji rektorskiej prof. Woźniaka Senat AM w Łodzi zatwierdził przemianowanie Zakładu Onkologii na Katedrę Onkologii. W skład Katedry wchodziły: Zakład Pato- logii Nowotworów, Klinika Chirurgii Onkologicznej, Klinika Chemioterapii Nowotworów i Pracownia Biologii Nowotworów. Decyzja Senatu wymagała akceptacji formalnej ministra zdrowia i opieki społecznej, co nastąpiło po roku 1990. Mimo to idea naszego Zarządu PTO, aby utworzyć samodzielne jednostki dydaktyczno-naukowe w randze katedr, klinik czy zakładów uczelnianych w uczelniach medycznych w Polsce, została zrealizowana do końca ubiegłego stulecia.

W czasie naszej kadencji w Zarządzie Głównym PTO roku 1980 odbyła się wizytacja polskich ośrodków onkologicznych przez przedstawicieli WHO i UICC: dr. D. Rice'a i D. Reeda (z naszym udziałem). Po wizytacji łódzkiego ośrodka onkologicznego odbyło się spotkanie w Pabianicach, organizowane przez prof. Bernera. Podczas tego spotkania i dyskusji wizytujący pozytywnie oceniali organizację i działalność polskich ośrodków onkologicznych. Podkreślali również wyraźny postęp polskiej onkologii. W załączeniu zdjęcia fotograficzne z wizytacji.

Gdy w latach 1990-1996 rektorem Akademii Medycznej w Łodzi został prof. Jan Berner, działalność w zakresie przeddyplomowego nauczania onkologii była nadal kontynuowana w ramach utworzonej Łódzkiej Katedry Onkologii. Od roku 1996 do roku 2002 kierownikiem Katedry był prof. J. Berner. Utworzył on w Katedrze Onkologii samodzielną pracownię medycyny paliatywnej, którą prowadzi dr Ciałkowska-Rysz, obecnie przewodnicząca Krajowej Rady ds. Opieki Paliatywnej. Prowadzi ona również zajęcia dydaktyczne (praktyczne i teoretyczne) dla studentów medycyny 5 roku.

Prof. dr hab. n. med. Jan Berner

e-mail:janek.berner@gmail.com 